Journal of Epidemiology and Public Health (2018), 3(3): 312-322

https://doi.org/10.26911/jepublichealth.2018.03.03.02

\title{
Predictors of Hypertension in Post-Menopausal Women in Surakarta, Central Java
}

\author{
Amalia Dinda Ayu Pradani'), Ambar Mudigdo²), Isna Qadrijati3) \\ 1)Masters Program in Public Health, Universitas Sebelas Maret \\ 2)Faculty Teaching and Educational Sciences, Universitas Sebelas Maret \\ 3)Faculty of Medicine, Universitas Sebelas Maret
}

\begin{abstract}
Background: Hypertension caused $45 \%$ mortality of heart disease and 51\% mortality of stroke in 2014. Young women have a lower risk of hypertension than men. The risk increases after menopause due to lower estrogen production. This study aimed to estimate the biopsychosocial factors affecting hypertension in post-menopausal women in Surakarta, Central Java.

Subjects and Method: This was an analytic observational study with a cross-sectional design. The study was conducted in Surakarta, Central Java, from January to February 2018. A sample of 200 study subjects was selected by fixed disease sampling. The dependent variable was hypertension. The independent variables were obesity, healthy diet, history of contraceptive use, family support, and family history of hypertension. Data of blood pressure was measured by sphygmomanometer. Other variables were measured by questionnaire. The data were analyzed by a multiple logistic regression.

Results: The risk of hypertension in post-menopuse women increased with obesity (OR=13.00; 95\% $\mathrm{CI}=2.99$ to $56.51 ; \mathrm{p}=0.001)$, family history of hypertension $(\mathrm{OR}=9.99 ; 95 \% \mathrm{CI}=2.54$ to 39.19 ; $\mathrm{p}=0.001)$, and history of hormonal contraceptive use (OR=10.11; 95\% $\mathrm{CI}=2.60$ to $39.25 ; \mathrm{p}=0.001)$. The risk of hypertension in post-menopuse women decreased with healthy diet (OR=0.16; 95\% $\mathrm{CI}=0.04$ to $0.55 ; \mathrm{p}=0.004)$ and strong family support $(\mathrm{OR}=0.09 ; 95 \% \mathrm{CI}=0.19$ to $0.39 ; \mathrm{p}=0.001)$.

Conclusion: The risk of hypertensionin post-menopause women is affected by obesity, family history of hypertension, history of hormonal contraceptive use, healthy diet, and strong family support.
\end{abstract}

Keywords: biopsychosocial, hypertension, post-menopause

\section{Correspondence:}

Amalia Dinda Ayu Pradani, Masters Program in Public Health, Universitas Sebelas Maret, Jl. Ir. Sutami 36 A, Surakarta 57126, Central Java. Email: pradaniamalia@gmail.com.

\section{BACKGROUND}

$\overline{\text { Every year, more than } 36 \text { million people die }}$ from non-communicable diseases. It is about $63 \%$ of all deaths in the world.The cause of death number one of noncommunicable diseases is a cardiovascular disease that is a disease caused by impaired heart and blood vessel function. Hypertension causes at least $45 \%$ of deaths from heart disease and $51 \%$ of deaths from stroke. This complication of hypertension causes about 9.4 million deaths worldwide each year which is expected to continue increasing to 23.3 million deaths by 2030 (Ministry of Health, 2014). The result of Basic Health Research 2013 shows that the prevalence of hypertension in Indonesia is based on the measurement in the population $>18$ years old by $25.8 \%$ (Ministry of Health Research and Development, Ministry of Health, 2013). In Central Java, the prevalence of hypertension is still above the national average of $26.4 \%$. The number of non-communicable diseases shows increased rates year by year and the incidence of hypertension tends to be higher in urban 
than in rural areas. In Central Java, Surakarta is the city with the highest prevalence of hypertension (Central Java Provincial Health Office, 2015). Data obtained from the Surakarta City Health Office (2016) shows that hypertension ranks first in noncommunicable diseases. The case found in 2015 from the reports of health centers and hospitals throughout the city of Surakarta was 55.970 cases for hypertension (DKK Surakarta, 2016). Based on Basic Health Research (2013) data state that women are more likely to have hypertension with a ratio of $\mathbf{1 2 . 2 \%}$ for women and $6.5 \%$ for men.

In young women, the risk of hypertension is lower than the risk in men. But the risks will increase after the menopause (Akishita and $\mathrm{Yu}, 2012$ ). This is because the decrease in estrogen production in postmenopausal women can lead to increase bad cholesterol (LDL) and decrease good cholesterol (HDL). The high LDL can cause narrowing and blockage of arterial blood vessels that can lead to circulatory and hypertensive disorders (Bybee, 2014). The number of elderly population in Indonesia by 2020 is estimated to be 28.8 million (11.34\%) with life expectancy of 71.1 year. Life expectancy in Central Java has increased annually to 72.4 years in 2010. Life expectancy in Surakarta City also continues to increase in 2015 up to 76.99 years. Annual Life Expectancy Improvement (UHH) every year is a proof of successful national development that has been implemented especially in the field of social welfare and health sector, but it can also cause problems of life in old age (Central Bureau of Statistics of Central Java Province, 2015). One of the problems that is often experienced in old age is the vulnerability of physical condition to various diseases including hypertension disease. Most people think hypertension is common in elderly people, so the majority of people underestimate the disease. Therefore, hypertension is called a "silent killer" because it can cause various complications such as heart failure and stroke that can cause death if not treated properly (Wulandhani et al., 2014).

Based on data from Basic Health Research (2013), it is known that the number of women is more likely to experience hypertension compared to men. The tendency of gaining weight, especially in the abdominal area in postmenopausal women may increase the risk of hypertension. Centrality is a condition in which a person has excess fat in the body, especially fat abdominal hypertension. Women with central obesity have a high risk of hypertension despite normal weight, so maintaining a normal waistline is more important than simply maintaining an ideal body weight (Bybee, 2014). In Indonesia, women are more central to obesity than men, $42.1 \%$ for women and $11.3 \%$ for men. The proportion of central obesity in people aged $>15$ years in Indonesia increased by $18.8 \%$ in 2007 to $26.6 \%$ in 2013. Another factor that may increase the risk of hypertension is the use of seasonings in cooking because it contains sodium substances that cause hypertension. In people who consume more than 6 grams of sodium per day, their blood pressure will increase more rapidly as the age also increases (Purwanto, 2012). For the consumption of risky food, in Indonesia, there are still many who consume seasoning that are for about $77.3 \%$ for age $>$ 10 tahun. A study from Zhou, et al (2015) showed the result that someone who has a family history with hypertension has a risk of 1.6 times suffering from hypertension than those without a family history of hypertension. Hormonal contraceptives can result in side effects of increased blood pressure that can lead to the risk of hypertensive disease (Bybee, 2014). Older wo- 
men using hormonal contraceptives (>2 years) had a risk of hypertension 2.95 times than those who are not (Lestari, 2013).

There are various factors that affect hypertension in postmenopausal women such as estrogen reduction, metabolic syndrome, obesity, anxiety and depression that can play an important role in the pathogenesis of postmenopausal hypertension (Yanes and Reckelhoff, 2013).

Family support may affect the incidence of hypertension. With the existence of high family support, it can control the factors of the occurrence of hypertension in postmenopausal women. Some factors that cause hypertension do not stand alone but can be influenced by other factors (Ojo et al., 2016).

Hypertension that occurs in postmenopausal women should be handled properly, because hypertension can be prevented if the risk factors can be controlled properly. Prevention and treatment of hypertension is an effort of independent health care initiative by health personnel and individual concerned that can be done through early detection of risk factors, healthy lifestyle implementation, and routine blood pressure checking through community-based activities. Based on the background, the author is interest to examine the predictors of biopsychosocial hypertension in postmenopausal women.

\section{SUBJECTS AND METHOD \\ 1. Study Design \\ This was an analytic observational study with a cross-sectional design. The study was conducted in Surakarta, from January to February 2018.}

\section{Population and Sample}

The target population in this study was all women who had been experiencing amenorrhea for more than 12 months, while the source population was women who had experienced amenorrhea for more than 12 months in Purwosari, Sangkrah, Sibela, Ngoresan, Setabelan, and Pucangsawit community healt centers, Surakarta. A sample of 200 study subjects was selected by fixed disease sampling, consisting of 100 cases and and controlls.

\section{Operational definition of variables}

Hypertension was defined as an abnormal increase in blood pressure in arteries with systolic blood pressure $>140 \mathrm{mmHg}$ and/ or diastolic $>90 \mathrm{mmHg}$. Hypertension was measured by Sphygnomanometer. The measurement scale was continuous, but for the purpose of data analysis, it was transformed into dichotomous, coded 1 for hypertension and o for non-hypertension.

Obesity was defined as a disorder or condition characterized by the accumulation of body fat tissue is excessive. Obesity measured is central obesity which the location of localized fat distribution is in the abdomen because it can cause health problems, especially cardiovascular disease. Measuring instruments use measuring waist tape. The data were collected by questionnaire. The measurement scale was continuous, but for the purpose of data analysis, it was transformed into dichotomous, coded 1 for obese (waist circumference size $\geq 80 \mathrm{~cm}$ ) and o for non obese (waist circumference size $<80 \mathrm{~cm}$ ).

Diet was defined as a pattern setting and consumption of food and beverages recommended, limited in number, and which should be avoided by patients with blood pressure above normal for the purpose of treatment of hypertensive diseases in accordance with the recommendation from Ministry of Health (2011). The data were collected by questionnaire. The measurement scale was continuous, but for the purpose of data analysis, it was transformed into dichotomous, coded 1 for good diet and $\mathrm{o}$ for poor diet. 
Genetic history was defined as a family history of the father, mother, grandfather, or grandmother who suffers from hypertension. The data were collected by questionnaire.The measurement scale was categorical.

History of hormonal contraceptive used were mothers who have history of using hormonal contraceptives such as pill, injection, or implants for more than 2 years. The data were collected by questionnaire. The measurement scale was categorical.

Anxiety was defined as the same uncomfortable feeling or anxiety accompanied by an autonomous response (the source is often non-specific or unknown to the individual), the fear of anticipation of danger. The measuring tool was a standard Zung Self Anxiety Rating Scale (ZSAR-S Zung-S) questionnaire with the reliability of 0.829 . The measurement scale was continuous, but for the purpose of data analysis, it was transformed into dichotomous, coded 1 for high anxiety (score $\geq 45$ ) and o for low anxiety (score <45).

Family support was defined as attitudes, acts of family acceptance of family members, in the form of informational, assessment, instrumental, financial, and emotional support. The data were collected by questionnaire. The measurement scale was continuous, but for the purpose of data analysis was transform into dichotomous, coded o for weak family support and 1 for strong family support.

\section{Data Analysis}

The data analysis of the result used multiple logistic regression analysis to know the influence of independent variable to dependent variable and to know the influence of the variable.

\section{Research Ethics}

The research ethical clearance was obtained from the Research Ethics Committee at Dr.
Moewardi Hospital, Surakarta, Central Java, Indonesia. Research ethics included issues such as informed consent, anonimity, confidentiality, and ethical clearance.

\section{RESULTS}

\section{Univariate Analysis}

Table 1 shows that from 200 study subjects, it was found that the age of postmenopausal women was 49-54 years old for about 5o people (25.0\%), 55-59 years of 67 people (33.5\%) and the highest was 60-65 years i.e. 83 mothers (41.5\%).

\section{Table 1. Univariate Analysis}

\begin{tabular}{|c|c|c|}
\hline Characteristics & $\mathbf{n}$ & \% \\
\hline \multicolumn{3}{|l|}{ Age } \\
\hline $49-54$ years old & 50 & 25.0 \\
\hline $55-59$ years old & 67 & 33.5 \\
\hline $60-65$ years old & 83 & 41.5 \\
\hline \multicolumn{3}{|l|}{ Education } \\
\hline$<$ Senior high school & 126 & 63.0 \\
\hline$\geq$ Senior high school & 74 & 37.0 \\
\hline \multicolumn{3}{|l|}{ Occupation } \\
\hline Working at home & 118 & 59.0 \\
\hline Working outside the house & 82 & 41.0 \\
\hline \multicolumn{3}{|l|}{ Obesity } \\
\hline Normal weight & 75 & 37.5 \\
\hline Obese & 125 & 62.5 \\
\hline \multicolumn{3}{|l|}{ Diet } \\
\hline Poor diet & 100 & 50.0 \\
\hline Good diet & 100 & 50.0 \\
\hline \multicolumn{3}{|l|}{ Genetic History of } \\
\hline Hypertension & 108 & 54.0 \\
\hline No & 92 & 46.0 \\
\hline Yes & & \\
\hline \multicolumn{3}{|l|}{ History of Hormonal } \\
\hline Contraceptive Use & 113 & 56.5 \\
\hline No & 87 & 43.5 \\
\hline \multicolumn{3}{|l|}{ Yes } \\
\hline \multicolumn{3}{|l|}{ Anxiety } \\
\hline Not anxious & 123 & 61.5 \\
\hline Anxious & 77 & 38.5 \\
\hline \multicolumn{3}{|l|}{ Family Support } \\
\hline Weak & 95 & 47.5 \\
\hline Strong & 105 & 52.5 \\
\hline
\end{tabular}

The level of maternal education is mostly still low, that is, there are 126 below SHS graduates (63.0\%) and senior high school and university graduates are 74 people (37.0\%). Most of the subjects were working at home for about 118 (59.0\%) and 
Journal of Epidemiology and Public Health (2018), 3(3): 312-322

https://doi.org/10.26911/jepublichealth.2018.03.03.02

working outside for about 82 people (41.0\%).

After measurement of waist circumference, most of the subjects that were categorized into the obese category were 125 people $(62.5 \%)$ and non-obese were 75 people (37.5\%). Subects who applied a diet that supports blood pressure control were about 100 people (50.0\%). This is comparable to those on a diet that does not support blood pressure control of 100 people (50.0\%).
Most of the study subjects had no family history of hypertension for about 108 people (54.0\%) and 92 (46.0\%) had a family history of hypertension. Most of the subjects did not have a history of hormonal use of 113 people (56.5\%), and 87 people (43.5\%) has a hormonal family history.

Most of the subjects had no anxiety as for about 123 people (61.5\%) and a few of them had anxiety for about 77 people (38.5\%). Most subjects had strong family support of 105 people $(52.5 \%)$ and poor family support of 95 people (47.5\%).

Table 2. Bivariate analysis of the relationship between independent variable and the incidence of hypertension in post-menopausal women

\begin{tabular}{|c|c|c|c|c|c|c|c|}
\hline \multirow[t]{2}{*}{$\begin{array}{l}\text { Independent } \\
\text { Variables }\end{array}$} & \multicolumn{2}{|c|}{ Hypertension } & \multicolumn{2}{|c|}{$\begin{array}{c}\text { Non- } \\
\text { hypertension }\end{array}$} & \multirow[t]{2}{*}{ OR } & \multirow[t]{2}{*}{$95 \% \mathrm{CI}$} & \multirow[t]{2}{*}{$\mathbf{p}$} \\
\hline & $\mathbf{n}$ & $\%$ & $\mathbf{N}$ & $\%$ & & & \\
\hline Obesity & & & & & & 13.79 to 88.18 & \\
\hline Not Obese & 6 & 8.0 & 69 & 92.0 & 34.87 & & $\mathrm{p}<0.001$ \\
\hline Obese & 94 & 75.2 & 31 & 24.8 & & & \\
\hline \multicolumn{8}{|l|}{ Diet } \\
\hline Poor diet & 82 & 82.0 & 18 & 18.0 & 0.48 & 0.02 to 0.09 & $\mathrm{p}<0.001$ \\
\hline Good diet & 18 & 18.0 & 82 & 82.0 & & & \\
\hline \multicolumn{8}{|l|}{$\begin{array}{l}\text { Genetic History of } \\
\text { Hypertension }\end{array}$} \\
\hline No & 25 & 23.1 & 83 & 76.9 & 14.64 & $7 \cdot 34$ to 29.22 & $\mathrm{p}<0.001$ \\
\hline Yes & 75 & 81.5 & 17 & 18.5 & & & \\
\hline \multicolumn{8}{|c|}{$\begin{array}{l}\text { History of Hormonal } \\
\text { Contraceptive Use }\end{array}$} \\
\hline No & 28 & 24.8 & 85 & 75.2 & 14.57 & 7.22 to 29.38 & $\mathrm{p}<0.001$ \\
\hline Yes & 72 & 82.8 & 15 & 17.2 & & & \\
\hline \multicolumn{8}{|l|}{ Anxiety } \\
\hline Not Anxious & 33 & 26.8 & 90 & 73.2 & 18.27 & 8.41 to 39.66 & $\mathrm{p}<0.001$ \\
\hline Anxious & 67 & 87.0 & 10 & 13.0 & & & \\
\hline \multicolumn{8}{|l|}{ Family Support } \\
\hline Weak Support & 82 & 86.3 & 13 & 13.7 & 0.03 & 0.01 to 0.07 & $\mathrm{p}<0.001$ \\
\hline Strong Support & 18 & 17.1 & 87 & 82.9 & & & \\
\hline
\end{tabular}

\section{Bivariate Analysis}

Bivariate analysis was performed to determine the relationship between variables, namely independent variables (obesity, diet, genetic history, history of hormonal contraceptive use, anxiety and family support) with dependent variable (hypertension). Bivariate analysis was performed using Chi-Square test and presented in Table 2.
Table 2 shows that genetic history $(\mathrm{OR}=14.64,95 \% \mathrm{CI}=7.34$ to $29.22, \mathrm{p}$ $<0.001)$, obesity $(\mathrm{OR}=34.87 ; 95 \% \mathrm{CI}=$ 13.79 to 88.18 ; $\mathrm{p}<0.001$ ), history of hormonal contraceptive $(\mathrm{OR}=14.57 ; 95 \% \mathrm{CI}=$ 7.22 to $29.38 ; \mathrm{p}<0.001$ ), and high anxiety $(\mathrm{OR}=18.27 ; 95 \% \mathrm{CI}=8.41$ to $39.66 ; \mathrm{p}$ $<0.001)$ were increased the risk of hypertension in post-menopausal women good $\operatorname{diet}(\mathrm{OR}=0.48 ; 95 \% \mathrm{CI}=0.02$ to 0.09 ; 
$\mathrm{p}<0.001)$, and family support $(\mathrm{OR}=0.03$; 95\% $\mathrm{CI}=0.01$ to $0.07 ; \mathrm{p}<0.001)$ with hypertension.

\section{Multivariate Analysis}

The result of multivariate analysis test can be seen in Table 3. Table 3 showed that there was a significant relationship between obesity, genetic history, history of hormonal contraceptive use, anxiety, diet, and family support with hypertension on postmenopausal women.

The risk of hypertension in menopausal women increased with obesity (OR=
13.0; $95 \% \mathrm{CI}=2.99$ to $56.51 ; \mathrm{p}=0.001)$, hormonal contraceptive use $(\mathrm{OR}=10.11$; 95\% $\mathrm{CI}=2.60$ to $39.25 ; \mathrm{p}=0.001$ ), and high anxiety $(\mathrm{OR}=3.89 ; 95 \% \mathrm{CI}=0.73$ to 20.85 ; $\mathrm{p}=0.112)$.

The risk of hypertension in menopausal women decreased with had not genetic history (OR=0.99; 95\% $\mathrm{CI}=2.54$ to 39.19 ; $\mathrm{p}=0.001)$, good $\operatorname{diet}(\mathrm{OR}=0.16 ; 95 \% \mathrm{CI}=$ 0.04 to $0.55 ; \mathrm{p}=0.004)$, strong family $(\mathrm{OR}=0.09 ; 95 \% \mathrm{CI}=0.19$ to $0.39 ; \mathrm{p}=$ o.001).

Table 3. The result of multivariate analysis with multiple logistic regression test

\begin{tabular}{|c|c|c|c|c|}
\hline \multirow[t]{2}{*}{ Independent Variables } & \multirow{2}{*}{$\mathbf{O R}$} & \multicolumn{2}{|c|}{ CI 95\% } & \multirow[b]{2}{*}{$\mathbf{p}$} \\
\hline & & Lower Limit & Upper Limit & \\
\hline Obesity & 13.00 & 2.99 & 56.51 & 0.001 \\
\hline Genetic history & 9.99 & 2.54 & 39.19 & 0.001 \\
\hline History of hormonal contraceptive use & 10.11 & 2.60 & 39.25 & 0.001 \\
\hline Anxiety & 3.89 & 0.73 & 20.85 & 0.112 \\
\hline Diet & 0.16 & 0.04 & 0.55 & 0.004 \\
\hline Family Support & 0.09 & 0.19 & 0.39 & 0.001 \\
\hline \multicolumn{5}{|l|}{$\mathrm{N}$ Observed $=200$} \\
\hline \multicolumn{5}{|l|}{-2 Log Likelihood= 71.08} \\
\hline \multicolumn{4}{|l|}{ Nagelkere R Square $=85.8 \%$} & \\
\hline Probability chi $^{2}<0.001$ & & & & \\
\hline
\end{tabular}

\section{DISCUSSIONS}

\section{The relationship between obesity and hypertension}

The results of multivariate analysis showed that there was a relationship between obesity and hypertension. Obesity increased the risk of hypertension in post-menopausal women.

The result of this study is consistent with a study by Zhou et al. (2015), which stated that there was a relationship between obesity and hypertension. This study showed that the prevalence of hypertension in post-menopausal women was greater than in pre-menopausal women. There was a relationship between central obesity and age. The older the age, the higher the risk of obesity. In post-menopausal women, central obesity was a higher risk factor in increasing hypertension than BMI. Obesity assessment using BMI cannot assess the distribution of body fat so it was less sensitive in describing the amount of visceral fat (Maryani, 2013). Central obesity can cause health problems such as hypertension, cardiovascular disease, type 2 diabetes mellitus, dyslipidemia, cancer, sleep apnea, and metabolic syndrome (Tchernof and Despres, 2013).

According to the data of Basic Health Research (2013), women in Indonesia were much more to experience central obesity than men, $42.1 \%$ for women and $11.3 \%$ for men. In addition, age changes were also known to be associated with changes in body composition, which was a decrease in fat-free mass and increased fat mass at the age of 20-30 years old (Tchernof and Despres, 2013). 
The result of this study was also in line with a study byTyagi et al. (2015), which stated that obesity was a risk factor for hypertension in women. The incidence of hypertension showed a positive association with obesity in post-menopausal women which was statistically significant. The percentage of fat in the body was higher in post-menopausal women than in pre-menopausal women. The study showed that $49 \%$ of central obesity was appear in post-menopausal women from the entire study subjects. Obesity in post-menopausal women increased the risk of hypertension, diabetes mellitus, and vascular disease. Based on the description above, it can be concluded that there was a relationship between obesity and hypertension in postmenopausal women.

\section{The relationship between genetic history and hypertension}

Multivariate test results showed that there was a relationship between genetic history and hypertension. Genetic history would increase the risk of hypertension in postmenopausal women.

The result of this study was in line with a study done by Valerio et al. (2016), which stated that there was a positive relationship between family history of hypertension and the incidence of hypertension. Based on that study, family history with symptoms of cardiovascular disease and stroke increased the prevalence of cardiovascular disease symptoms.Hypertension in individuals with a family history was found to be almost twice as high as hypertension in individuals without a family history, therefore, family history may be used clinically to identify an individual's risk of hypertension.

Familiy member who had hypertension and heart disease increased the risk of hypertension by 3-4 times compared to families with no history of hypertension
(Hartono, 2013).A child's blood pressure would be similar to blood pressure of his/ her blood-related parents than the adopted child because the inherited gene played a major role in determining blood pressure (Palmer, 2007).

The result of this study was also in line with a study by Zhouet al.(2015), which stated that there was a relationship between family history of hypertension and the incidence of hypertension in women. This study stated that the history of hypertension and cardiovascular disease in the family would increase the risk of hypertension. Based on the description above, it can be concluded that there was a relationship between genetic history and hypertension in post-menopausal women.

\section{The relationship between history of hormonal contraceptive use and hypertension}

Multivariate test results showed that there was a relationship between history of hormonal contraceptive useand hypertension. History of hormonal contraceptive use would increase the risk of hypertension in post-menopausal women.

The result of this study was in line with a meta-analysis study by Liu et al. (2017) which stated that there was a relationship between a history of hormonal contraceptive use and hypertension in women. Women who use hormonal contraceptives, which in the study were pills can increase the risk of hypertension.Any $5^{-}$ year enhancement in oral contraceptive use may increase the risk of hypertension by $13 \%$.

The result of a study by Park and Kim (2013) showed that the use of hormonal contraceptives was associated with the incidence of hypertension. In women with longer duration in using hormonal contraceptives was positively associated with an enhancement of systolic blood pressure and 
diastolic blood pressure compared to women who had not taken hormonal contraceptives. In addition, women who used hormonal contraceptives for more than 24 months were also statistically associated with an increased risk of prehypertension and hypertension.

The use of hormonal contraceptives containing estrogen and progesterone hormones can lead to an increase in blood pressure.This was due to the occurrence of cardiac hypertrophy and increased angiotension II presor response by involving the path of Renin Angiotensin System (Olatunji, 2008).

The result of this study was also in line with a study byLestari (2013) which stated thatthere was a relationship between the duration of the use of hormonal contraceptive methods with the incidence of hypertension. Women who used the hormonal contraceptive method for a long time which was more than two years were at higher risk of developing hypertension than women who did not use hormonal contraceptives. Based on the description above, it can be concluded that there was a relationship between history of hormonal contraceptive use and hypertension in postmenopausal women.

\section{The relationship between anxiety and hypertension}

Multivariate test results showed that there was a relationship between anxiety and hypertension. Anxiety would increase the risk of hypertension in post-menopausal women.

The result of this study was in line with a study done by Pan and Yu (2015) which stated thatthere was a relationship between anxiety with an enhancement risk of hypertension. Hypertension has aetiology caused by various factors, namely biological factors, environmental factors, psychological, and social.Anxiety was one of the most common psychological factors possessed by adults who can interfere with health problems, one of them was hypertension.

Anxiety that arised in menopausal women was often associated with concerns in facing the situation that never happened before, such as anxiety due to physiological and psychological changes marked by the end of the reproductive period (Varney, 2007). Anxiety can arise due to stress. The relationship between stress and hypertension was suspected through sympathetic nervous activity, which can increase blood pressure gradually. The anxiety can stimulate the kidney gland to release the adrenaline hormone and stimulate the heart to beat faster and stronger, therefore, the blood pressure would increase. If it lasted long enough, the body tried to make adjustments so that pathological changes occur in the body that can lead to the emergence of hypertension symptoms (Manik, 2012)

The result of this study is consistent with a study by Bacon et al. (2014). This study examined the relationship between psychological factors and hypertension conducted through psychiatric interviews. The results showed that there was a relationship between anxiety with the incidence of hypertension. The incidence of hypertension was more common in patients with high anxiety. The enhancement of anxiety can also lead to unhealthy behavior patterns such as smoking, drinking, and lack of physical activity such as exercise that may cause an enhancement risk of hypertension. Based on the description above, it can be concluded that there was a relationship between anxiety and hypertension in post-menopausal women.

\section{The relationship between diet and hypertension}

Multivariate test results showed that there was a relationship between dietand hyper- 
tension. By doing a dutiful diet, it would reduce the risk of hypertension in postmenopausal women.

The result of this study was in line with Geaney et al. (2015) who stated that research subjects with higher nutritional knowledge would be more applying a quality diet and have lower risk to suffer from hypertension. A good nutritional knowledge was positively associated with dietary quality. A good diet can lower blood pressure. Based on this study, it can be concluded that the prevalence of hypertension can be reduced by improving the quality of individual diets. Dietary compliance has been shown to decrease the risk of cardiovascular disease. Diet foods with low consumption of fat, sodium, processed foods/ preservatives, and increase intake of fruits and vegetables can significantly lower the blood pressure in people with hypertension.

Based on the result of a study by Kim and Andrade (2016), a person with a diagnosis of hypertension indicated a lack of adherence to a hypertensive diet than someone who was not diagnosed with hypertension. The status of hypertension was associated with increased consumption of saturated fats, sodium, total fat, and protein. A hypertensive diet was highly recommended for someone who has high blood pressure and hypertensive diet adherence has been shown to be effective for controlling the hypertension.

Based on the description above, it can be concluded that there was a relationship between diet and hypertension in postmenopausal women.

\section{The relationship between family support and hypertension}

Multivariate test results showed that there was a relationship between family support and hypertension. Strong family support would decrease the risk of hypertension in post-menopausal women.
Family support may affect the incidence of hypertension. With strong family support, it can control the factor of hypertension in post-menopausal women. The result of this study was in line with a study by Ojo et al. (2016) which showed thatthere was a strong family support to the surrounding community that can control the rise in blood pressure, therefore, only a few of these people who were found to be suffering from hypertension. Hypertensive patients with high family support also have good hypertensive treatment therapy adherence than patients with low family support (Olowookere et al., 2015).

This study was also in line with Wulandhani et al. (2014) who stated that there was a significant relationship between family support and the motivation to check the blood pressure in elderly who have hypertension. Elderly with strong family support have a high motivation to check their blood pressure. With a high motivation to check the blood pressure, the risk of hypertension was lower because high blood pressure can be known early and get the treatment immediately.

Based on the description above, it can be concluded that there was a relationship between family support and hypertension in post-menopausal women.

\section{REFERENCES}

Akishita M, Yu J (2012). Hormonal effects on blood vessels, Hypertension Research. Nature Publishing Group, 35(4): 363-369. doi: 10.1038/hr.2012.4 .

Bacon SL, Campbell TS, Arsenault A, Lavoie KL (2014). The Impact of Mood and Anxiety Disorders on Incident Hypertension at One Year. Int $\mathrm{J}$ Hypertens. 953094. doi: 10.1155/2014/953094.

Badan Penelitian dan Pengembangan Kese- 
hatan Kementerian Kesehatan RI (2013). Riset Kesehatan Dasar. Available at: http://www.depkes.go.id/resources/-download/general/HasilRiskesdas 2013.pdf .

Badan Pusat Statistik Provinsi Jawa Tengah (2015). Profil lansia jawa tengah 2015. Bybee K, Dew M, Lawhorn S, Stevens T (2014). Penyakit Kardiovaskular pada Wanita. Jakarta: Erlangga.

Dinas Kesehatan Kota Surakarta (2016). Profil Kesehatan Kota Surakarta Tahun 2015.

Dinas Kesehatan Provinsi Jawa Tengah (2015). Profil Kesehatan Provinsi Jawa Tengah. Dinas Kesehatan Provinsi Jawa Tengah. Available at: dinkesjatengprov.go.id/v2015/dokumen/profil2015/Profil_2015_fix.pdf

Geaney F, Fitzgerald S, Harrington JM, Kelly C, Greiner BA, Perry IJ (2015). Nutrition knowledge, diet quality and hypertension in a working population. PMEDR. Elsevier B.V., 2: 105-113. doi: 10.1016/j.pmedr.2014.11.008.

Hartono A (2013). Terapi Gizi \& Diet Rumah Sakit. Jakarta: EGC.

Kementerian Kesehatan RI (2011). Diet Hipertensi. Direktorat Bina Gizi Subdit Bina Gizi Klinik. http://gizi.depkes.go.id/wpcontent/uploads/201 3/o8/Brosur-Diet-Hipertensi.pdf (2014). Situasi Kesehatan Jantung. Available at: http://www.depkes.go.id/download.php?file=download/.../infodatin/infodatin-jantung.pdf.

Kim H, Andrade FCD (2016). Diagnostic status of hypertension on the adherence to the Dietary Approaches to Stop Hypertension (DASH) diet. PMEDR. The Authors, 4: 525-531. doi: 10.1016/j.pmedr.2016.09.009.

Lestari IP (2013). Hubungan Antara Lama Penggunaan Metode.

Liu H, Yao J, Wang W, Zhang D (2017).
Association between duration of oral contraceptive use and risk of hypertension : A meta-analysis. 1032-1041. doi: $10.1111 /$ jch.13042.

Manik M (2012).Faktor-faktor yang Berhubungan dengan Hipertensi pada Lansia di Posyandu Lansia Wilayah Kerja Puskesmas Parsoburan Kecamatan Siantar Marihat Pematang Siantar Tahun 2011. Universitas Sumatera Utara. Skripsi.

Maryani (2013). Jantung Koroner di Rsud Kabupaten Sukoharjo (The Ratio of Waist and Hip Circumference to Coronary Heart Desease at the Sukoharjo District Hospital). Buletin Penelitian Sistem Kesehatan, 16: 7382.

Ojo OS, Malomo SO, Sogunle PT (2016). Blood pressure (BP) control and perceived family support in patients with essential hypertension seen at a primary care clinic in Western Nigeria. 569-575. doi: 10.4103/2249-4863.197284 .

Olowookere A, Olowookere S, Talabi A, Etonyeaku A, Adeleke O, Akiboboye O (2015). Annals of Tropical Medicine and Public Health. 8(6).

Pan Y, Cai W, Cheng Q, Dong W, An T, Yan $\mathrm{J}$ (2015). Association between anxiety and hypertension: a systematic review and meta-analysis of epidemiological studies. Dove Press: 11211130.

Park H, Kim K (2013). Associations between oral contraceptive use and risks of hypertension and prehypertension in a cross-sectional study of Korean women. BMC Women's Health. 13(1): 1. doi: 10.1186/1472-6874-13-39.

Purwanto (2012). Hipertensi (patogenesis, kerusakan taget organ, danpenatalaksanaan). Surakarta: UNS Press.

Tchernof A, Després J (2013). Pathophysio- 
Journal of Epidemiology and Public Health (2018), 3(3): 312-322

https://doi.org/10.26911/jepublichealth.2018.03.03.02

logy of human visceral obesity: an update biology of abdominal adipose aspects of regional body fat distribution. Physiol Reviews. 359-404. doi: 10.1152/physrev.00033.2011.

Tyagi R, Dhall M, Kapoor S (2015). BioSocial Predictors of Hypertension Among Premenopausal and Postmenopausal Women. SAGE Open, 1. doi: $10.1177 / 2158244015574227$.

Valerio L, Peters RJ, Zwinderman AH (2016). Association of Family History With Cardiovascular Disease. Journal of the American Heart Association. 110. doi: 10.1161/JAHA.116.004260.

Varney H (2007). Buku Ajar Asuhan Kebidanan Edisi 4 Volume 2. Jakarta:
EGC.

Wulandhani SA, Nurchayati S, Lestari W (2014). Hubungan dukungan keluarga dengan motivasi lansia hipertensi dalam memeriksakan tekanan darahnya. $1-10$.

Yanes L, Reckelhoff J (2013). NIH Public Access. 24(7). doi: 10.1038/ajh.2011.71.Postmenopausal.

Zhou Y, Zhou X, Guo X, Sun G, Li, Z, Zheng L, Yang H, et al. (2015). Prevalence and Risk Factors of Hypertension among Premenopausal and Postmenopausal Women: A cross-sectional Study in a Rural Area of Northeast China. Maturitas. 80(3). doi: 10.1016/j.maturitas.2014.12.001. 